\title{
Effect of centchroman on tubal transport and preimplantation embryonic development in rats
}

\author{
M. M. Singh, V. Bhalla, V. Wadhwa and V. P. Kamboj \\ Division of Endocrinology, Central Drug Research Institute, Lucknow-226001, India
}

\begin{abstract}
Summary. A single oral administration of centchroman $(1.25 \mathrm{mg} / \mathrm{kg})$ to adult female rats within $24 \mathrm{~h}$ of mating induced slight acceleration in the rate of transport of embryos through the oviducts. The compound did not seem to produce any deleterious effect on preimplantation embryonic development since well organized and apparently normal embryos were collected from the genital tract up to Day 12 of pregnancy. The recovery rate of embryos from centchroman-treated rats was, however, significantly reduced after Day 4 of pregnancy. There was some stimulation in the rate of cleavage of embryos and morula to blastocyst transformation, but retardation in the shedding of the zona pellucida. The rate of blastocyst formation was not altered when 6-8-cell embryos collected from the oviducts of control rats were transferred to the uteri of control or centchroman-treated females. A delay in zona shedding was observed in the centchroman-treated recipients.
\end{abstract}

\section{Introduction}

Centchroman (3,4-trans-2,2-dimethyl-3-phenyl-4- $p$ ( $\beta$-pyrrolidinoethoxy)phenyl-7-methoxychroman), a nonsteroidal contraceptive currently under multicentric clinical trial, has been reported to inhibit decidualization in rats and mice (Kamboj, Singh \& Kar, 1973; Singh \& Kamboj, 1981). In mice, it induced 'tube-locking' of embryos at the ampullary-isthmic junction of the oviducts and a significant reduction in the rate of cleavage of embryos, morula to blastocyst transformation and shedding of the zona pellucida (Singh \& Kamboj, 1981). The 'tube-locked' embryos recovered between Days 4 and 12 post coitum, when surgically transferred to the uteri of control pseudopregnant females, gave significantly reduced pregnancy and implantation rates and an increased post-implantation resorption rate. However, the fetuses developing to term in foster mothers were devoid of any teratological effects and showed normal growth rate and fertility performance at puberty (Singh, Wadhwa, Sethi \& Kamboj, 1983).

Since the induction of 'tube-locking' in response to weak oestrogens is specific to mice (Bennett, 1970) and since from these studies it has not been ascertained whether the observed differences were due to environmental effects or to effects of the compound or both, we have studied in detail the effect of centchroman on tubal transport and preimplantation embryonic development in rats.

\section{Materials and Methods}

The colony bred adult Sprague-Dawley rats $(180-250 \mathrm{~g})$ were maintained at the Institute, in airconditioned $\left(24 \pm 1^{\circ} \mathrm{C}\right)$ quarters and under uniform husbandry conditions. The animals were kept in cages in groups of 10 and were given a pellet diet (Hind Levers Ltd, Bombay) and tap water ad libitum. Females were caged overnight with coeval males of proven fertility ( 1 male : 5 females) and were examined for the presence of spermatozoa in their vaginal smears on the following morning. The day of presence of spermatozoa in the smear was taken as Day 1 of pregnancy. 
A group of mated rats was treated with a single oral contraceptive dose $(1.25 \mathrm{mg} / \mathrm{kg}$; Kamboj, Setty, Chandra, Roy \& Kar, 1977) of centchroman, synthesized at this Institute, suspended in glassdistilled water with an equal amount of gum acacia on Day 1 of pregnancy. Animals of the control group received the vehicle alone in a similar manner. Animals of both the groups were killed by cervical dislocation at about 09:00 and 18:00 h daily on Days 2, 3, 4, 5, 6,8,10 and 12 of pregnancy. Animals killed after Day 4 received an i.v. injection of $0.5 \mathrm{ml} 1 \%$ pontamine sky blue 5 BX (GT Gurr Ltd, London, U.K.) in $0.9 \%(\mathrm{w} / \mathrm{v})$ sodium chloride under ether anaesthesia $15 \mathrm{~min}$ before autopsy for localization of implantation sites. The procedures for centchroman treatment and collection of embryos were the same as described for mice (Singh \& Kamboj, 1981). For preparation of cell spreads, embryos treated with $1 \%$ aqueous sodium citrate for 3-5 min at room temperature were transferred in $2-5 \mu \mathrm{l}$ of the citrate solution to a clean microslide. A mixture of methanol:acetic acid $(3: 1, v / v)$ added drop wise on one side of the slide was allowed to flow over the embryos, taking the citrate solution along with it and was soaked up by a filter-paper strip placed on the other side. The embryos could be seen under an AO Zoom Stereomicroscope (model $561 \mathrm{C}-\mathrm{H} 1)$ to swell before bursting. Once dry, the cells stuck to the surface of the slide. More methanol:acetic acid mixture could be added to achieve complete spreading. The spreads were air dried, stained with $1 \%$ aqueous toluidine blue for $15 \mathrm{~min}$ and washed with water.

For embryo transfers, the technique described for mice (Singh et al., 1983) was employed. The medium used by Toyoda \& Chang (1974) for culturing rat embryos in vitro was prepared in the laboratory using chemicals purchased from Sigma, St Louis, MO, U.S.A., sterilized by passing through a millipore filter (pore size $0.22 \mu \mathrm{m}$ ) and used for collection and transfer of embryos. The $\mathrm{pH}$ of the medium was adjusted to about 7.4 with sterile $5 \% \mathrm{CO}_{2}$ in air before use. The 6-8-cell embryos were collected from the oviducts of control females on the morning of Day 4 of pregnancy, washed 2-3 times with the sterile medium and immediately transferred to the uteri of synchronized recipient female rats. The recipients had been mated to fertile male rats, treated with a single oral contraceptive dose $(1.25 \mathrm{mg} / \mathrm{kg})$ of centchroman or the vehicle alone on Day 1 of pregnancy and had the utero-tubal junction bilaterally ligated on Day 2 of pregnancy. On average, 6 embryos were transferred in $0.2-0.5 \mu \mathrm{l}$ medium to each uterine horn. The recipients were killed by cervical dislocation at 12, 24, 36 or $48 \mathrm{~h}$ after transfer. Each uterine horn was flushed with $0.5-1 \mathrm{ml}$ medium. The number and stage of development of embryos were recorded and cell spreads were prepared on microslides according to the procedure described above.

Response variables quantitative in nature were subjected to analysis of variance (two-way classification) after transforming to square roots in order to stabilize variances amongst treatment groups. Time and drug effects were adjusted for nonorthogonality because of the different numbers of animals in different groups. Linear contrasts were applied to compare individual effects. In embryo transfer studies (Table 2), the numbers of embryonic cells at various times were considered as binomial variates and the significance of the drug effect was tested by Cochrane's test.

A $\chi^{2}$ test was applied to test the significance of proportions of embryos shedding the zona pellucida and forming blastocysts. When the expected frequencies were less than 5 , exact probabilities were determined.

\section{Results}

\section{Embryo recovery studies}

Centchroman treatment $(1.25 \mathrm{mg} / \mathrm{kg})$ within $24 \mathrm{~h}$ of mating induced slight acceleration in the rate of tubal transport of embryos and morula to blastocyst transformation, but a delay in shedding of the zona pellucida. The compound did not seem to produce any deleterious effect on the development of embryos to the blastocyst stage as well organized and apparently normal embryos were recovered from the genital tract up to Day 12 of pregnancy. 
Table 1. Effect of centchroman on the recovery of preimplantation embryos from the oviducts and uterus of rats

\begin{tabular}{|c|c|c|c|c|c|c|c|}
\hline \multirow{2}{*}{\multicolumn{2}{|c|}{$\begin{array}{c}\text { Time } \\
\text { post coitum }\end{array}$}} & \multicolumn{3}{|c|}{ Control rats } & \multicolumn{3}{|c|}{ Centchroman-treated rats } \\
\hline & & No. of & & & No. of & & \\
\hline Day & Hour & rats & Oviducts & Uterus & rats & Oviducts & Uterus \\
\hline 2 & 09:00 & 6 & $12 \cdot 0 \pm 2 \cdot 1(6)$ & - & 6 & $13 \cdot 3 \pm 1 \cdot 3(6)$ & - \\
\hline $\begin{array}{l}3 \\
3\end{array}$ & $\begin{array}{l}09: 00 \\
18: 00\end{array}$ & $\begin{array}{l}6 \\
6\end{array}$ & $\begin{array}{l}11 \cdot 0 \pm 1 \cdot 3(6) \\
11 \cdot 8 \pm 1 \cdot 0(6)\end{array}$ & - & $\begin{array}{l}8 \\
6\end{array}$ & $\begin{array}{r}9 \cdot 3 \pm 1 \cdot 8(8) \\
10 \cdot 2 \pm 0 \cdot 7(6)\end{array}$ & - \\
\hline $\begin{array}{l}4 \\
4\end{array}$ & $\begin{array}{l}09: 00 \\
18: 00\end{array}$ & $\begin{array}{l}6 \\
8\end{array}$ & $\begin{array}{r}10 \cdot 7 \pm 1 \cdot 7(6) \\
7 \cdot 0 \pm 0 \cdot 7(7)\end{array}$ & $6 \cdot \overline{ \pm} \cdot 8(3)$ & $\begin{array}{l}6 \\
6\end{array}$ & $\begin{array}{r}8 \cdot 0 \pm 2 \cdot 3(3) \\
10 \cdot 0 \pm 0 \cdot 0(1)\end{array}$ & $\begin{array}{l}6 \cdot 0 \pm 1 \cdot 4 \quad(6) \\
7 \cdot 7 \pm 1 \cdot 4 \quad(6)\end{array}$ \\
\hline $\begin{array}{l}5 \\
5\end{array}$ & $\begin{array}{l}09: 00 \\
18: 00\end{array}$ & $\begin{array}{l}6 \\
8\end{array}$ & - & $\begin{array}{r}9.3 \pm 0.7(6) \\
11.5 \pm 1.0(8)\end{array}$ & $\begin{array}{l}6 \\
6\end{array}$ & - & $\begin{array}{l}6 \cdot 3 \pm 1 \cdot 2^{*}(6) \\
5 \cdot 0 \pm 0 \cdot 9^{*}(6)\end{array}$ \\
\hline 6 & 09:00 & 5 & - & $12 \cdot 2 \pm 0 \cdot 7(5)$ & 6 & - & $5 \cdot 3 \pm 0 \cdot 7^{*}(6)$ \\
\hline 8 & 09:00 & 6 & - & $11 \cdot 8 \pm 1 \cdot 3(6)$ & 6 & - & $5 \cdot 8 \pm 0.9 *(6)$ \\
\hline 10 & 09:00 & 6 & - & $11 \cdot 0 \pm 0 \cdot 5(6)$ & 6 & - & $6 \cdot 5 \pm 1 \cdot 3 *(6)$ \\
\hline 12 & 09:00 & 6 & - & $10 \cdot 2 \pm 0.7(6)$ & 6 & - & $4.5 \pm 0.9 *(6)$ \\
\hline
\end{tabular}

Values are mean \pm s.e.m., with number of animals containing embryos/implantations in parentheses. In the control group values below the horizontal rule indicate implantations.

* $P<0.05$, compared with controls at the corresponding times.

In control rats, the first sign of entry of embryos into the uterus was discerned on the evening of Day 4, but in centchroman-treated rats $60 \%$ of the 60 embryos had already entered the uterus on the morning of Day 4, suggesting about $12 \mathrm{~h}$ stimulation in the rate of transport of embryos through the oviducts (Table 1). A similar number of embryos was recovered from the oviducts of

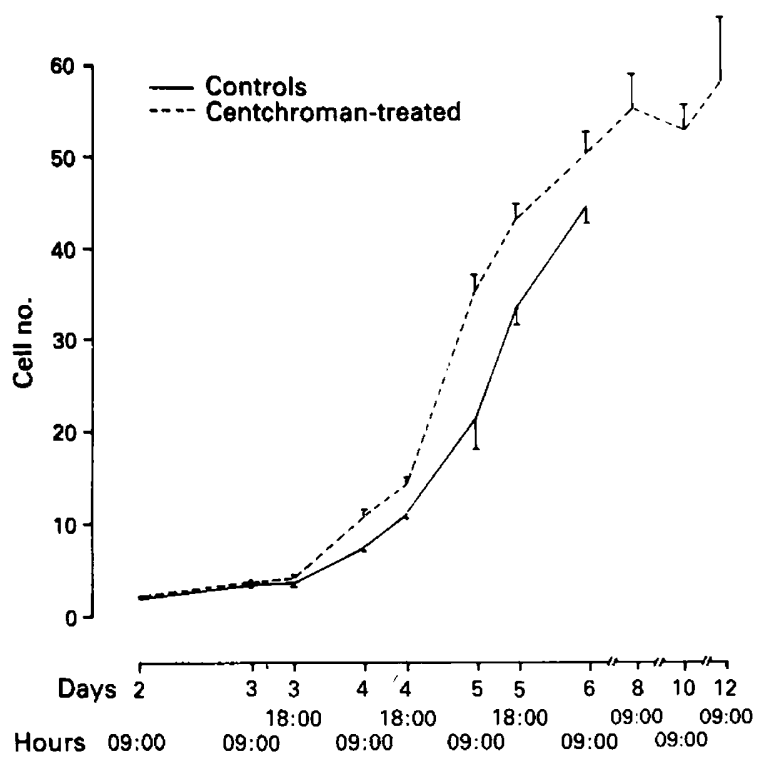

Fig. 1. Average number of cells in embryos recovered from control and centchroman-treated rats. Vertical bars indicate standard error. 
control and centchroman-treated rats, but a significant $(P<0.05)$ interaction indicating differential response in the two groups was evident after entry of embryos into the uterus, since at each time significantly $(P<0.05)$ fewer embryos were recovered from centchroman-treated females than the corresponding controls after Day 4 post coitum (Table 1 ).

The rate of blastocyst formation in centchroman-treated rats was also stimulated by about $12 \mathrm{~h}$. In animals of the control group, all embryos recovered on Day $4(18: 00 \mathrm{~h})$ were in the morula stage and blastocyst formation was observed on the morning of Day 5 . In comparison, in the treated animals the process was initiated on the evening of Day 4 , when $21 \%$ of the 56 embryos were in the blastocyst stage, and was completed by the morning of Day 5 .

In contrast, a delay in shedding of the zona pellucida was observed in animals treated with centchroman. While the process of zona shedding began at almost the same time in both groups of rats (i.e. 18:00 h on Day 5), fewer zona-free blastocysts were recovered from centchroman-treated rats $(20 \%$ compared with $65 \%$ in controls, $P<0.01)$. On Day $6(09: 00 \mathrm{~h})$, the process of implantation had already been initiated in control rats, as indicated by the pontamine blue
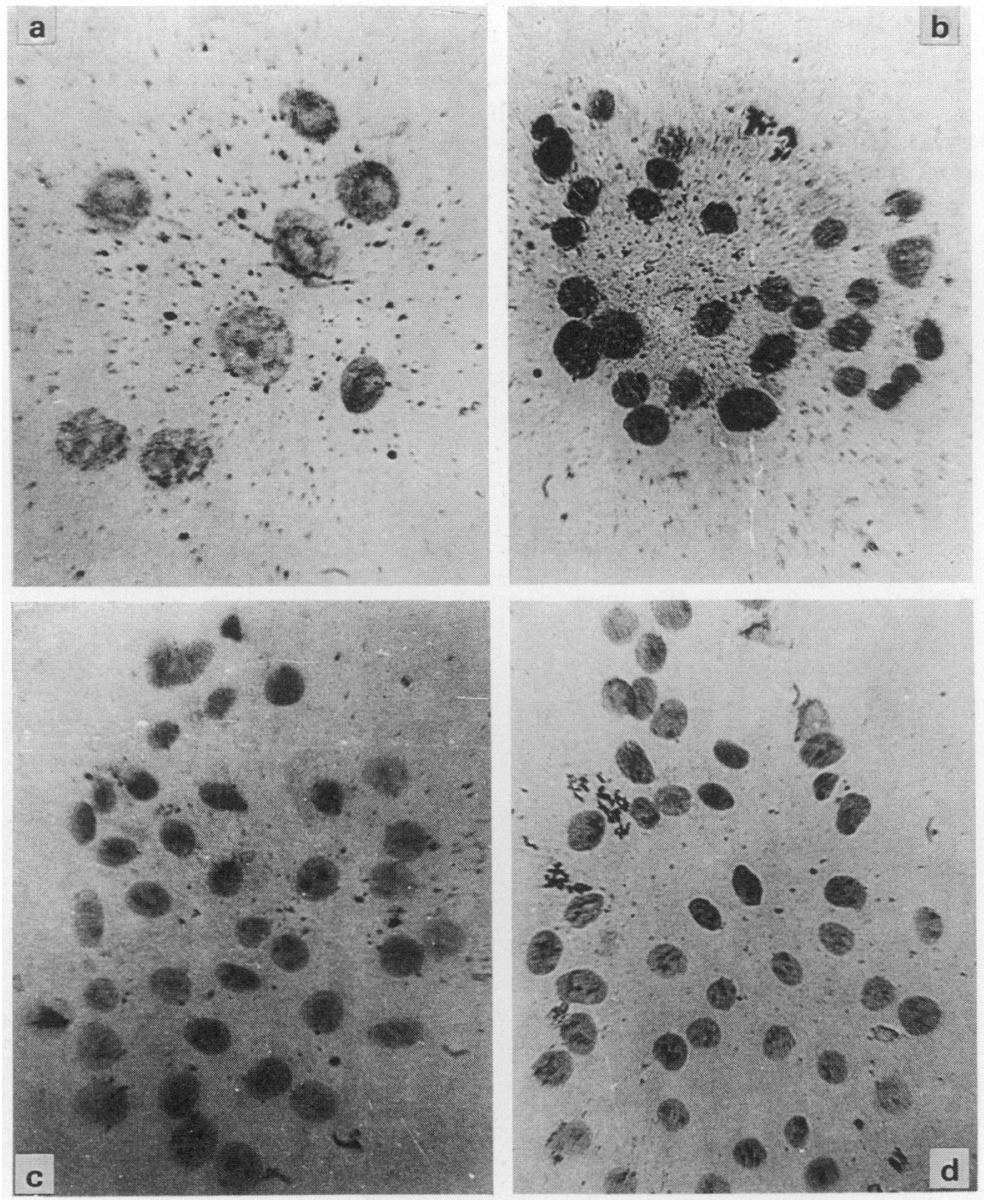

Fig. 2. Spreads of embryos obtained from the genital tract of control rats. (a) Day $4(09: 00 \mathrm{~h}), 8$ cells, $\times 310$; (b) Day $5(09: 00$ h), 30 cells, $\times 225$; (c) Day 5 $(18: 00$ h), 35 cells, $\times 225$; (d) Day 6 $(09: 00 \mathrm{~h}), 44$ cells, $\times 225$. 
reaction, but 2 out of 32 blastocysts recovered from centchroman-treated rats were still zona encapsulated. All blastocysts recovered after Day 6 were, however, zona free.

Embryonic cell number followed a similar pattern in both the groups until Day $3(18: 00 \mathrm{~h})$ of pregnancy. However, after Day 3, embryonic cell number in centchroman-treated females was significantly $(P<0.05)$ greater than that of the corresponding controls at all times, indicating a marked stimulation of the cleavage rate after treatment with centchroman (Figs 1-3). Maximum cell number in both groups of embryos was achieved on the morning of Day 6 and very little cleavage was observed in embryos recovered from centchroman-treated females after Day 6, the average cell number remaining virtually unaltered until Day 12 of pregnancy.

\section{Embryo transfer studies}

There was little difference in the rate of development of 6 8-cell control embryos after transfer to the uteri of control or centchroman-treated rats. The embryos developed into morulae within $12 \mathrm{~h}$ after transfer and their average cell number was 12.41 and $14 \cdot 11$ respectively $(P>0.05)$.
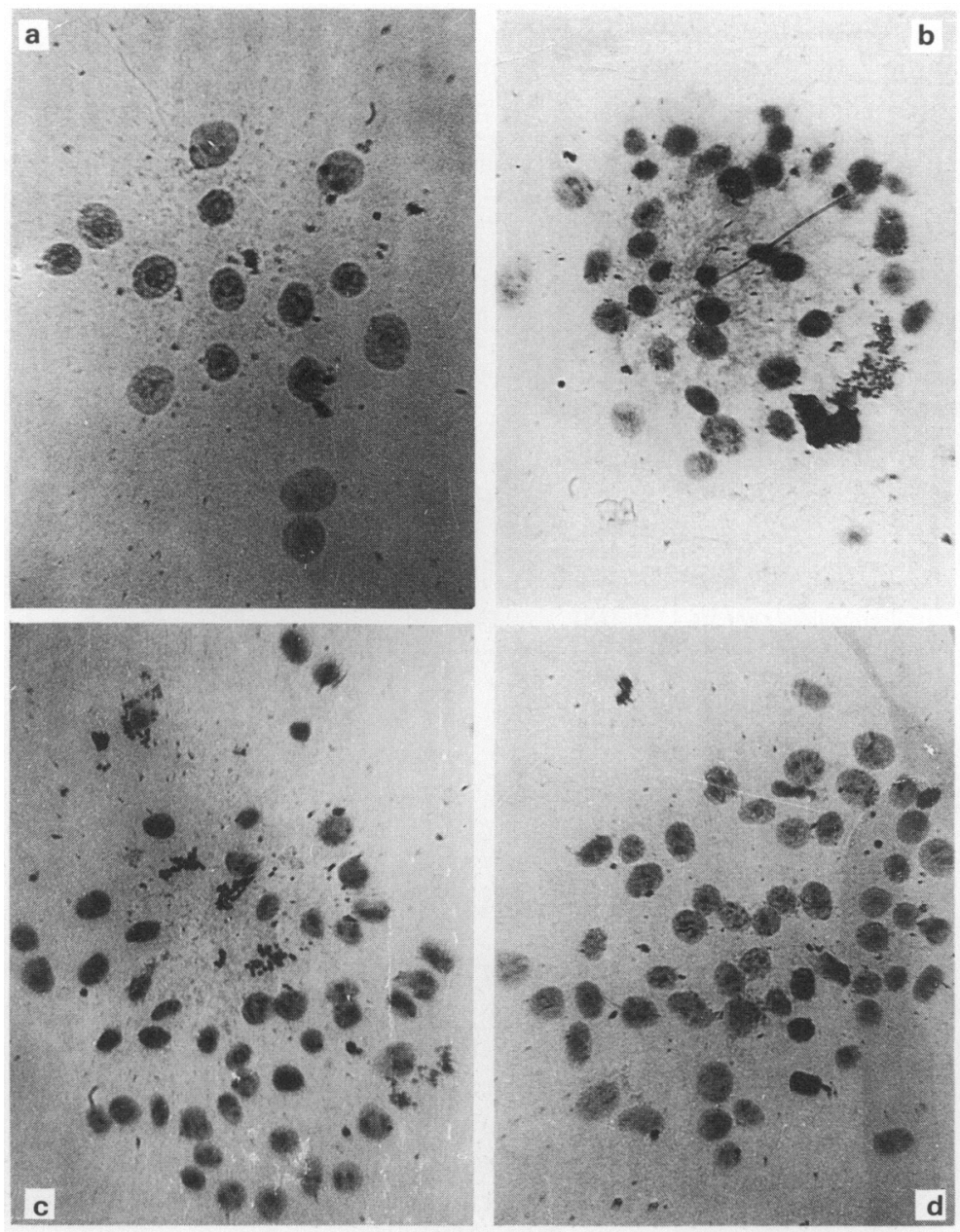

Fig. 3. Spreads of embryos obtained from the genital tract of centchroman-treated rats. (a) Day $4(09: 00 \mathrm{~h}), 15$ cells, $\times 290$; (b) Day $5(09: 00 \mathrm{~h}), 35$ cells, $\times 225$; (c) Day $6(09: 00 \mathrm{~h}), 52$ cells, $\times 225$; (d) Day $12(09: 00 \mathrm{~h}), 56$ cells, $\times 225$. 
Morula to blastocyst transformation was initiated at almost the same time in both groups and, at $24 \mathrm{~h}$ after transfer, 81 and $89 \%$ of the embryos recovered from control and centchroman-treated recipients respectively were in the blastocyst stage, the process being completed at $36 \mathrm{~h}$ in both the groups. The increase $(P<0.01)$ in embryonic cell number in the two groups was also similar at each time (Table 2).

There was, however, a marked delay in the shedding of the zona pellucida in recipients treated with centchroman. In controls, the first sign of zona shedding was observed at $24 \mathrm{~h}$ when about $19 \%$ of the recovered blastocysts were zona free, but all those recovered up to $36 \mathrm{~h}$ from centchroman-treated recipients were still encapsulated in the zona. It was not until $48 \mathrm{~h}$ that zona-free blastocysts could be recovered from centchroman-treated recipients, suggesting a delay of about $24 \mathrm{~h}$ in the initiation of this process (Table 2).

Healthy implantation sites were seen in control recipients at $48 \mathrm{~h}$, but no implantations were observed in centchroman-treated recipients and apparently normal blastocysts were recovered from the uteri at this time (Table 2).

Table 2. Blastocyst formation, zona shedding and implantation of 6-8-cell control rat embryos at various times after transfer to uteri of control or centchroman-treated females

\begin{tabular}{|c|c|c|c|c|c|c|c|c|}
\hline & \multicolumn{4}{|c|}{ Control recipients } & \multicolumn{4}{|c|}{ Centchroman-treated recipients } \\
\hline & $12 \mathrm{~h}$ & $24 \mathrm{~h}$ & $36 \mathrm{~h}$ & $48 \mathrm{~h}$ & $12 \mathrm{~h}$ & $24 \mathrm{~h}$ & $36 \mathrm{~h}$ & $48 \mathrm{~h}$ \\
\hline No. of recipients $\dagger$ & 6 & 7 & 6 & 6 & 6 & 10 & 6 & 6 \\
\hline No. of embryos transferred & 58 & 73 & 64 & 61 & 82 & 120 & 58 & 56 \\
\hline No. of implantations & - & - & - & 32 & - & - & - & - \\
\hline No. of embryos recovered & 18 & 27 & 16 & -9 & 24 & 56 & 20 & 16 \\
\hline \multicolumn{9}{|l|}{ Stage of development } \\
\hline Morulae & 18 & 5 & - & & 24 & 6 & - & - \\
\hline Blastocysts & - & 22 & 16 & & - & 50 & 20 & 16 \\
\hline Zona pellucida $\ddagger$ & +18 & $\begin{array}{r}+22 \\
-5\end{array}$ & $\begin{array}{r}+6 \\
-10\end{array}$ & & +24 & +56 & +20 & $\begin{array}{r}+2 \\
-14\end{array}$ \\
\hline Embryonic cells & $12 \cdot 14$ & $21 \cdot 22^{*}$ & $38 \cdot 14^{*}$ & & $14 \cdot 11$ & $20 \cdot 15^{*}$ & $34 \cdot 00^{*}$ & $53 \cdot 33^{*}$ \\
\hline (mean \pm s.e.m.) & $\begin{array}{r} \pm 0 \cdot 82 \\
(15) \S\end{array}$ & $\begin{array}{c} \pm 1.47 \\
(18)\end{array}$ & $\begin{array}{c} \pm 3.94 \\
(14)\end{array}$ & & $\begin{array}{c} \pm 0.91 \\
(17)\end{array}$ & $\begin{array}{c} \pm 1 \cdot 20 \\
(22)\end{array}$ & $\begin{array}{c} \pm 2 \cdot 10 \\
(14)\end{array}$ & $\begin{array}{c} \pm 4 \cdot 21 \\
(16)\end{array}$ \\
\hline
\end{tabular}

$†$ Day 4 of pregnancy.

\$+ Present, - absent.

$\S$ Total number of embryos used for cell spreads.

T) Uterus not flushed.

* $P<0 \cdot 01$, compared with earlier value of the same group.

\section{Discussion}

The results of this study indicate that centchroman administered within $24 \mathrm{~h}$ of mating to adult female rats induced slight acceleration in the rate of transport of embryos through the oviducts and morula to blastocyst transformation, but a significant delay in shedding of the zona pellucida. However, when 6-8-cell embryos recovered from the oviducts of control rats were transferred to the uteri of control or centchroman-treated females, the rate of blastocyst formation was found to be almost similar. Therefore, the increased rate of blastocyst formation observed in animals treated post-coitally with a contraceptive dose of centchroman might be due only to an early entry of embryos into the uterus rather than to an effect of the compound.

Some nonsteroidal oestrogens/antioestrogens are known to cause a similar stimulation in the rate of tubal transport of embryos, due probably to their inherent oestrogenicity. This has, at least partly, been attributed to their mode of contraceptive action (Bennett, 1970; Hodgen, 1976). In the 
present study, we have observed a significant decrease in the number of embryos recovered from centchroman-treated rats after Day 4 post coitum, which might be due to a slightly earlier $(\sim 12 \mathrm{~h})$ entry of embryos into the uterus. However, while this might contribute to the contraceptive action of centchroman, it does not appear to affect embryonic development and viability since transfers of 6-8-cell tubal embryos to the uteri of control rats at least $12 \mathrm{~h}$ in advance of their normal time of entry into the uterus have yielded normal implantations in this study.

Post-coital treatment with centchroman (Kamboj et al., 1977), MER-25 (Kobayashi, Hisato \& Tamotsu, 1970), tamoxifen (Watson, Anderson, Alam, O'Grady \& Heald, 1975) and nafoxidine (Yoshida \& Kraig, 1969) has been reported to induce a type of 'delayed implantation' in the rat and the blastocysts, which remain in utero, implant after administration of exogenous oestrogen. We have been able to recover well organized and apparently normal embryos from the genital tract of centchroman-treated rats until Day 12 of pregnancy. The blastocysts collected after Day 6 were generally large and expanded, as has been observed during embryonic diapause (Baevsky, 1963; Schlafke \& Enders, 1963).

In comparison to controls, there was, however, a significant delay in the shedding of the zona pellucida in embryos recovered from centchroman-treated rats. Zona shedding was also delayed when 6-8-cell control embryos were transferred to the uteri of centchroman-treated females. A significant delay in zona shedding has been observed in mice and rats undergoing experimentally induced delayed implantation (Dickmann \& DeFeo, 1967; Rumery \& Blandau, 1971). It is not possible to assign any specific reason for the delayed loss of the zona pellucida after centchroman treatment. However, since under normal conditions the involvement of oestrogen in zona denudation in rodents has been suggested (Psychoyos, 1966; Wu, Dickmann \& Johnson, 1971; Dickmann, 1972; Surani, 1975), the delay in this process after centchroman treatment might be due to its antioestrogenic activity. It is not known whether centchroman induces this effect by a direct action on the embryos or is mediated via its inhibitory action on the genital tract function. While the compound has been shown to inhibit decidualization in rats and mice (Kamboj et al., 1973; Singh \& Kamboj, 1981), no evidence of the entry of centchroman or any other nonsteroidal oestrogen/ antioestrogen into the uterine milieu is so far available in the literature. Some nonsteroidal antioestrogens, such as clomiphene, tamoxifen, nafoxidine, U-11555A and CI-628, inhibit preimplantation embryonic development in vitro (Thomson, 1968; Andrade, Guimaraes \& Guerra, 1972; Pugh \& Sumano, 1979; Sengupta, Roy \& Manchanda, 1981; Roy, Sengupta, Paria \& Manchanda, 1982), but we have observed an increased rate of cleavage and blastocyst formation in animals treated post-coitally with a contraceptive dose of centchroman. It therefore seems that centchroman administered orally does not enter the genital tract milieu in concentrations sufficient to affect embryonic development and that the inhibition observed with the other antioestrogens in vitro might only be due to their nonphysiological concentrations in the medium. Pertinently, none of these compounds exhibit's embryotoxic activity in vivo (Blye, 1970).

The results of this study indicate that the contraceptive efficacy of centchroman can be related to an alteration of the oestrogen-sensitive implantation process by virtue of its antioestrogenic activity, rather than to a direct action on the preimplantation embryos. Slight acceleration of tubal transport might be an additional factor contributing to the contraceptive action.

We thank Dr Nitya Anand for his keen interest in the study; the Ministry of Health and Family Welfare, Government of India for financial assistance; Mr S. K. Mandal for statistical analysis; and Miss T. S. Kunjumol for typing the manuscript.

\section{References}

Andrade, A.T.L., Guimaraes, C.S. \& Guerra, M.O. (1972) The in vitro effects of clomiphene citrate on 6 day rabbit blastocysts and their subsequent in vivo development. Fert. Steril. 23, 841-846.
Baevsky, U.B. (1963) The effect of embryonic diapause on the nuclei and mitotic activity of mink and rat blastocysts. In Delayed Implantation, pp. 141-153. Ed. A. C. Enders. University of Chicago Press. 
Bennett, J.P. (1970) The effects of drugs on egg transport. Adv. Biosci. 4, 165-178.

Blye, R.P. (1970) The effect of estrogens and related substances on embryonic viability. $A d v$. Biosci. 4, 323-342.

Dickmann, Z. (1972) Effects of progesterone, medroxyprogesterone acetate (Provera) and oestrone on shedding and dissolution of the zona pellucida in the rat. J. Endocr. 54, 3945.

Dickmann, Z. \& DeFeo, V.J. (1967) The rat blastocyst during normal pregnancy and during delayed implantation, including an observation on the shedding of zona pellucida. J. Reprod. Fert. 13, 3-9.

Hodgen, B.J. (1976) Effects of indomethacin and ICI 46474 administered during ovum transport on feriility in rabbits. Biol. Reprod. 14, 451-457.

Kamboj, V.P., Singh, M.M. \& Kar, A.B. (1973) Effect of some nonsteroidal antifertility agents on biochemistry of the uterus and uterine fluid in rats. Indian $J$. exp. Biol. 11, 479-485.

Kamboj, V.P., Setty, B.S., Chandra, H., Roy, S.K. \& Kar, A.B. (1977) Biological profile of centchroman-a new postcoital contraceptive. Indian J. exp. Biol. 15, 1144-1150.

Kobayashi, F., Hisato, K. \& Tamotsu, M. (1970) Delayed implantation induced by antiestrogenic compounds in rats. Endocrinol. jap. 17, 313-321.

Psychoyos, A. (1966) Influence of oestrogen on the loss of zona pellucida in the rat. Nature, Lond. 211, 864 .

Pugh, D.M. \& Sumano, H.S. (1979) The effects of oestradiol-17 $\beta$ and tamoxifen on the development of mouse embryos cultured over collagen. $\mathrm{Br}$. J. Pharmacol. 67, 458.

Roy, S.K., Sengupta, J., Paria, B.C. \& Manchanda, S.K. (1982) In vitro inhibition of trophoblast maturation and expansion of early rat blastocysts by an estrogen antagonist. Acta endocr., Copenh. 99, 129-135.

Rumery, R.E. \& Blandau, R.J. (1971) Loss of zona pellucida and prolonged gestation in delayed implantation in mice. In Biology of the Blastocyst, pp. 115-129. Ed. R. J. Blandau. University of Chicago Press.
Schlafke, S. \& Enders, A.C. (1963) Observations on the fine structure of the rat blastocyst. J. Anat. 97, 353-363.

Sengupta, J., Roy, S.K. \& Manchanda, S.K. (1981) Effect of an antioestrogen on implantation of mouse blastocysts. J. Reprod. Fert. 62, 433-436.

Singh, M.M. \& Kamboj, V.P. (1981) Effect of centchroman on preimplantation embryonic development and tubal transport in mice. Biol. Reprod. 25, 171-180.

Singh, M.M., Wadhwa, V., Sethi, N. \& Kamboj, V.P. (1983) Viability and development of 'tube-locked' mouse embryos. J. Reprod. Fert. 68, 165-170.

Surani, M.A.H. (1975) Zona pellucida denudation, blastocyst proliferation and attachment in the rat. $J$. Embryol. exp. Morph. 33, 343-353.

Thomson, J.L. (1968) Effect of two non-steroidal antifertility agents on pregnancy in mice. I. Comparison of in vitro and in vivo effects on zygotes. J. Reprod. Fert. 15, 223-231.

Toyoda, Y. \& Chang, M.C. (1974) Fertilization of rat eggs in vitro by epididymal spermatozoa and the development of eggs following transfer. J. Reprod. Fert. 36, 9-22.

Watson, J., Anderson, F.B., Alam, M., O'Grady, J.E. \& Heald, P.J. (1975) Plasma hormones and pituitary luteinizing hormone in the rat during the early stages of pregnancy and after postcoital treatment with tamoxifen (ICI 46474). J. Endocr. 65, 7-17.

Wu, J.T., Dickmann, Z. \& Johnson, D.C. (1971) Effects of oestrogen and progesterone on the development, oviductal transport and uterine retention of eggs in hypophysectomized pregnant rats. J. Endocr. 51, 569-574.

Yoshida, K. \& Kraig, J.M. (1969) Further studies on the mechanism of action of antiestrogen (U 11555A) on the inhibition of pregnancy in the rat. Fert. Steril. 20, 674-678. 